This is a postprint version of the following published document:

Méndez Rodríguez, E. M. \& Montero, A. (2007). Assessing information professionals in Dominican Republic: Are they prepared to deal with the new democratic libraries? International Information and Library Review, 39 (2), pp. 89-102.

DOI: $10.1016 /$ j.iilr.2007.02.010

(C) Elsevier, 2007

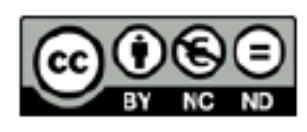

This work is licensed under a Creative Commons Attribution-NonCommercialNoDerivatives 4.0 International License. 


\title{
Assessing information professionals in Dominican Republic: Are they prepared to deal with the new democratic libraries?
}

\author{
Eva M. Méndez ${ }^{\mathrm{a}, *}$, Aida E. Montero \\ a'Librarianship and Information Science Department, University Carlos III of Madrid, \\ C/Madrid, 128 (Office. 14.2.17), 28903 Getafe, Madrid, Spain \\ ${ }^{\mathrm{b}}$ Knowledge Management and Information Center of FUNGLODE \\ (Fundación Global Democracia y Desarrollo), Santo Domingo, Dominican Republic
}

\begin{abstract}
Current information policies in Dominican Republic include the creation and development of libraries and information systems in a more effective way than ever in the country. One of the biggest concerns regarding these new democratic and modern libraries is to analyze whether the Dominican Republic has information professionals competent enough to deal with this new information system. This paper describes a thorough study of the Librarianship and Information Science (LIS) education in the country, as a first step to find out the needs and requirements for innovation in LIS education. Some of the topics analyzed are degrees and programs (in public and private universities), number of librarians and information professionals at graduate level, continuing education, a comparative overview with Latin American and Caribbean countries and conclusions. This article will show some of the results from a series of studies intended to enhance libraries and information infrastructure in Dominican Republic.
\end{abstract}

*Corresponding author. Tel./fax: +34916248620.

E-mail address: emendez@bib.uc3m.es (E.M. Méndez).

\section{Introduction}

If a library is a collection of materials, containing information, ideas and works of imagination, which are organized for use and staffed by people trained to make them available (Shimmon, 2003), nobody will deny having well-trained information professionals is an important part of the success of such a collection. If we add to this the Internet phenomenon and the new digital users' attitude, more than ever, we need a library staff of trained professionals who can guarantee democratic access to the information on the World Wide Web. Nowadays, a user needs to access materials through libraries which should have skilled staff available to search efficiently and to identify authentic sites and to obtain access to paid-for sources through site 
licenses. All of this points toward agreeing upon a growing set of standards, protocols, needed to construct the Information Society.

For the second half of the past century one of the most important factors of librarianship evolution was the creation of schools of Library and Information Sciences (LIS) with the imprimatur of a University. Those Library, or LIS, schools were and still are, in spite of the new challenges they have, the core place for managing theories, practices and attitudes in the library profession.

When different countries start down the path to deal with Information Society challenges, one of the main issues in social, political, economic and technological terms is the education of the professionals who will lead the effort to meet those challenges. Information and Communication Technologies (ICTs) have had an impact on nations and citizens all around the world, regardless of their political or socioeconomic systems. Libraries and information systems are strategic pieces of the socioeconomic growth in developing countries, particularly in Latin America and the Caribbean. Nevertheless, in this region library services are not always provided with qualified staff (Morales Campos, 1997, p. 118). With the Information Society requirements, the vertiginous changes in information needs and management, and the democratizing power of ICTs, qualified information professionals are expected to be the key to dealing with new libraries and information services, simultaneously managing and reducing the "digital divide".

LIS Education in developing countries has been a subject of interest in professional literature and research; even the International Federation of Library Associations (IFLA) Education and Training Section has recently created a discussion group about LIS Education in Developing Countries (IFLAETS, 2006). The international information \& $\mathrm{Li}^{-}$ brary Review journal has also reflected this interest over the years (for instance, Gupta \& Gupta, 1997; Kargbo, 1999). In different international contexts, IFLA and UNESCO are endeavoring to alert the government leaders of the importance of LIS education and to analyze LIS Education programs by regions. Latin American and Caribbean countries are usually studied together, leaving particular national overviews blurred by the vision of a set of countries (for instance in Fang, Stueart, \& Tuamsuk, 1995; Johnson, 2001; Licea de Arenas, 2001; Maris \& Giunti, 1999; Morales Campos, 1997). There are also particular associations, organizations, and events engaged in coordinating, analyzing and improving LIS studies in Latin America and the Caribbean. Included in this group are EDIBCIC
(Asociación de Educadores e Investigadores de Bibliotecología, Archivología, Ciencias de la Información y Documentación de lberoamérica y el Caribe $^{1}$ ), INFOBILA Seminar ${ }^{2}$ and the Special Interest Groups (SIG) in regional associations, such as ACURIL (Association of Caribbean University, Research and Institutional Libraries in the Caribbean $^{3}$ ). The situation of LIS education is usually well analyzed and described in the case of some IberoAmerican and Caribbean countries like Brazil, Argentina, Chile, Uruguay (Tannuri de Oliveira \& Chaves Guimaraes, 2004), Mexico, Venezuela, Colombia, Peru, Puerto Rico or Cuba, due usually to their tradition in LIS studies and research. However, analysis of Dominican Republic librarianship education and human resources training is most of the time reduced, at best, to one little note or a narrow vision (Maris \& Giunti, 1999, pp. 181-182; Rodríguez, 2006 ${ }^{4}$ ). This is probably because the information about LIS education is not sufficient (in the bibliography nor on the Web ${ }^{5}$ ), to be properly reflected in general overviews or in specific national approaches. This situation made it necessary to make an in situ and qualitative analysis as we did for this paper.

\footnotetext{
${ }^{1} \mathrm{EDIBCIC}$ : Association of Educators and Researchers on Librarianship, Archive Science, Information Science and Documentation of Ibero America and Caribbean /http://www. edibcic.org $>E D I B C I C$ comes from different meetings with educators in Librarianship to establish knowledge, experiences and resources interchange, to shape actions addressed to integration and cooperation to foster Information Science, in order to consolidate reading and informed societies.

${ }^{2}$ INFOBILA (información y Blbliotecología Latinoamericana) is a database of abstracts of Latin American publications in the field 〈http://www.bnv.bib.ve/bdinfobila.htm〉 produced for the CUIB (University Center of Librarianship Research) at UNAM in Mexico, in order to join, organize and diffuse Latin American literature on Librarianship and Information Sciences. Once in a while, INFOBILA people organize seminars and activities to improve education and research in Library Sciences in Latin America and Caribbean (see Martínez Arellano \& Calva González,
} 2005).

${ }^{3}$ ACURIL: 〈http://acuril.uprrp.edu 〉.

${ }^{4}$ In fact, Adolfo Rodríguez cites Maris and Giunti's previous study of 1999; thus the information about the schools with known programs in LIS in Dominican Republic, are exactly the same in both works.

${ }^{5}$ In a note above we highlighted the lack of bibliography about LIS studies in Dominican Republic, since most of the authors cite the same sources. Furthermore, despite some information that we have found on the Web more or less easily, for some information about the courses and studies imparted in Dominican Republic, there is not enough clarity. Sometimes even their own web pages and sites are misleading. For example, the academic program on LIS at INTEC (Instituto Tecnológico de Santo Domingo) 〈http://www.intec.edu.do/programas/hum/bci. $h t m l>$ could be found on the Web, but it has never been taught (cf. Current LIS education and training experiences). 


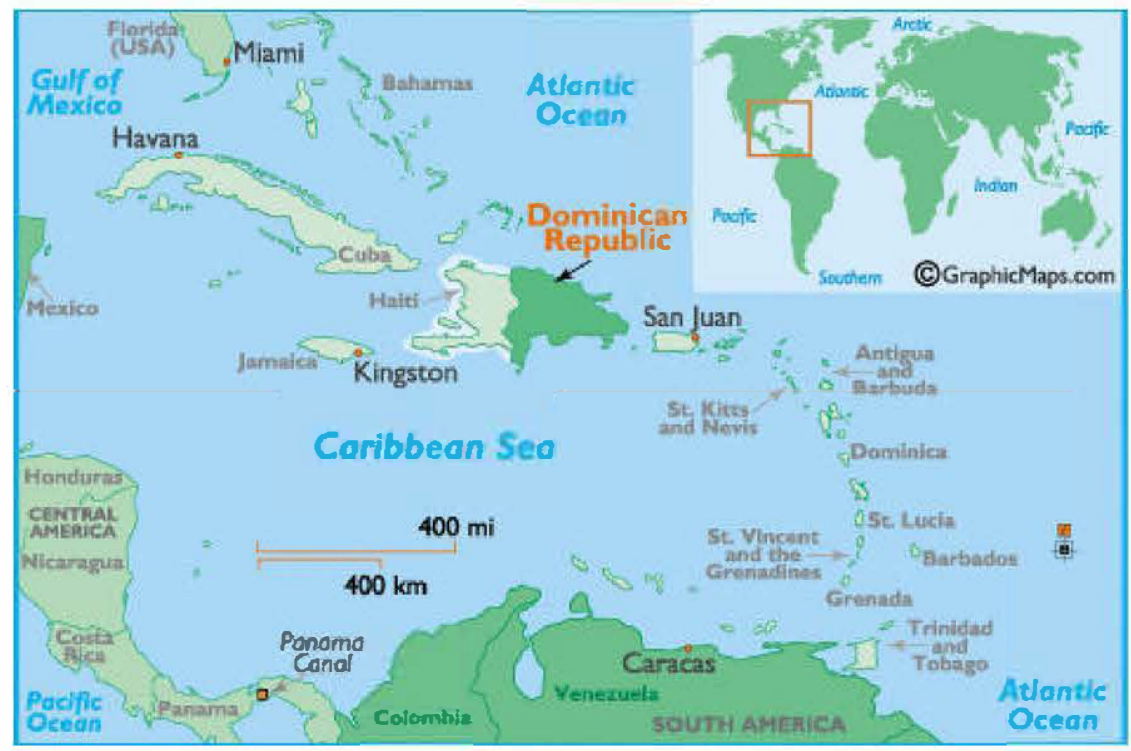

Figure 1 Geographic situation of Dominican Republic. Note: Map provided by:〈http://worldatlas.com〉.

It is traditionally understood that there is a clear relationship between librarian and information professionals' education and the library's development. In general, poor information systems had poor curriculum development. This situation has been noticed in other countries, for instance Sri Lanka, which is also an island country like the Dominican Republic (Karisiddappa, 2004). Notwithstanding this perception, the current information and cultural policies in the Dominican Republic in the last few years have created and developed a richer information infrastructure all around this country, but the education still has a poor curriculum.

In this article, we will reflect the results of an in situ qualitative analysis about past and current educational trends in LIS in this country. We will make an appraisal of the situation, and we will identify some ways to improve the education of Dominican librarians and information professionals, who should deal with the challenge of the new democratic access to information in the country and the information policies developed by the government.

\section{Dominican Republic and new democratic libraries}

Dominican Republic is an island country located on the eastern two-thirds of the Caribbean island of Hispaniola, bordering Haiti; it lies west of Puerto Rico and east of Cuba and Jamaica. It has more than nine million habitants. ${ }^{6}$ It has 31 provinces and the national capital, Santo Domingo, is contained within its own National District (Fig. 1).

As in other Latin American countries, the biggest development and population concentration is in the capital. Santo Domingo, located in the Southern part of the island, has more than two million habitants and most of the services of the country. About half of the Dominicans live in rural areas; many of them are small landholders, and Haitians form the largest foreign minority group around the country.

The politics of the Dominican Republic take place in a framework of a presidential representative democratic republic, whereby the president of the Dominican Republic is both head of state and head of government. The country has a multi-party political system with national elections held every two years (alternating between presidential elections and congressional/municipal elections). Executive power is exercised by the government. Legislative power is vested in both the government and the two chambers of the National Congress.

\section{Economy, education and culture in the country}

The Dominican Republic had one of the fastest growing economies in the world in the 1990s. After

\footnotetext{
${ }^{6}$ According with CIA World FactBook <https://www.cia.gov/ cia/publications/factbook/geos/dr.html $\rangle$ exactly 9,183,984 (estimated July 2006), but the List of Countries by Population in 2005 in Wikipedia /http://en.wikipedia.org/wiki/List_of_ countries_by_population_in_2005 > collocated Dominican Republic as the 87 th country in the world with $8,895,000$ habitants.
} 
a decade of crises in the 1980 s, the Dominican Republic's economy boomed, expanding at an average rate of $7.7 \%$ per year from 1996 to 2000 . Tourism (the leading foreign exchange earner), telecommunications, and free trade zone manufacturing are increasingly important industries, although agriculture is still a major part of the economy. The Dominican Republic owed much of its success to the adoption of sound macroeconomic policies in the early 1990 s and greater opening to foreign investment. The current administration obtained required tax legislation and International Monetary Fund board approval in January 2005. Inflation was cut sharply in late 2004 and the real growth rate of the Gross Domestic Product (GDP) was estimated at $9.3 \%$ for $2005 .^{7}$

Education in the country reveals that the school population has multiplied, but the quantitative growth has not been parallel to the qualitative development of the educational system's structures (Núñez de Taveras, 1997) because the illiteracy rate is still high. Educational structure implies initial, primary, secondary, and higher education, where primary education is officially free and required till the age of 14 . Relatively few lower-income students succeed in reaching secondary studies, although there are international programs to enhance education in the country. ${ }^{8} \mathrm{~A}$ low proportion of students attend private schools, which are frequently sponsored by religious institutions. Some public and private vocational education is available for a small percentage of the population. Around 38 universities make up the higher education system in Dominican Republic, but it is difficult to identify more than 20 of them on the Web. ${ }^{9}$ The academic level of these universities is very uneven. There is only one public university, the Autonomous University of Santo Domingo, known as UASD, founded in 1538 and considered the oldest institution of higher education in the New World. Not all universities have a library. There are other private universities, most of them in the capital, such as, Pedro Henríquez Ureña National University, APEC University and Technolo-

\footnotetext{
${ }^{7}$ CIA World FactBook: CIA World FactBook: 〈https://www.cia. gov/cia/publications/factbook/geos/dr.html $\rangle$.

${ }^{8}$ This is the case, for example of Dominican Republic Education And Mentoring (DREAM), which is a North American project providing equitable access to quality education for children born into poverty in rural areas and small communities of the Dominican Republic.

${ }^{9}$ For example, Universia, the biggest IberoAmerican portal about Universities, lists only 12 〈http://www1.universia.net/ catalogaxxi/C10032PPESII1/S10154/P10091NN1/INDEX.HTML> and the Catalogue of World Universities, only 18\langle\rangle http:// $w w w$.webometrics.info/university_by_country. asp-country=do.htm>.
}

gical Institute (INTEC). There are also some important universities outside the capital, like Madre y Maestra Pontifical Catholic University (PUCMM), based in Santiago de los Caballeros which also has a campus in the capital, and Central del Este University, in San Pedro de Macorís.

\section{Overview of libraries and information services in the country: information for development}

It is not easy to state an exact number of libraries and information services in the Dominican Republic, on the one hand because there is no recently updated directory or inventory of the libraries in the country ${ }^{10}$ and on the other hand because new libraries and information centers have appeared lately.

There are different kinds of libraries in the country: those created and maintained by the State, and private libraries belonging to private universities or institutions. Different surveys have different data and the statistical studies are not frequent enough $(1989,2000)$. At this time 505 libraries have been identified in the country: one National Library, 13 University Libraries, 43 public / municipal; 413 school libraries and 29 specialized libraries (Núñez de Taveras, 1997).

Historically, library development has been slow in the country. For instance, in 1927 the president Horacio Vásquez promulgated Law number 666 which created the National Library and the National Museum, but it would be only in 1971, under the Joaquín Balaguer government when the National Library was really inaugurated. In 1989 the "Biblioteca República Dominicana" (Dominican Republic Library) was created, a kind of public library of State, sometimes mistakenly referred to as a National Library. During the dictatorship, the University Library of the Universidad Autónoma de Santo Domingo (UASD) performed the National Library's functions from 1948 to 1971, and so the bibliographic heritage of the country is still dispersed and not very well organized or controlled. During the 1960 s and 1970 s, several private university libraries appeared, which in some ways extended their services to the society because of the lack of public libraries (Núñez de Taveras, 2006). The biggest general information growth in the country started in 1995, which coincided with

\footnotetext{
${ }^{10}$ This situation will change soon because we plan to create a Who is Who in LIS in Dominican Republic, which could be used as a starting point to identify libraries and information services in the country. Besides, the National Library is also about updating the directory of state libraries.
} 
the creation of international information policies to develop a Global Information Society. ${ }^{11}$ In that year, the Secretary of Education, with funds from the Inter-American Development Bank, implemented a project for a school library system in the country to strengthen basic education programs. In 1998, the Secretary of Culture inaugurated the special program called "Mobile Libraries System" to promote reading in deprived areas of the country (Núñez de Taveras, 2006).

In the last five years of the twentieth century, the development of telecommunications also took off in this country. In 1995 the Dominican Republic entered the Internet world, with dial-up services provided by national companies (Codetel and Tricom) (INDOTEL, 2004). In 1998, the Telecommunications General Act (No. 153-98) ${ }^{12}$ was promulgated to ensure the right of access to ICTs in the country.

In recent years, the growth in Dominican Republic can be measured not only with economic data but also cultural ones. The current government has defined a cultural and technological policy that includes libraries and information systems development throughout the country (Fernández, 2004). Likewise, the Government is enhancing the technological information infrastructure to bring the Information Society to Dominicans, creating, for example, the Presidential Office of Information and Communication Technologies $\left(\mathrm{OPTIC} \mathrm{C}^{13}\right.$ ) to boost eGovernment in the country. The Dominican Republic had in 200581,598 national hosts and 800,000 Internet users. ${ }^{14}$ Furthermore, we can point out several new and modern libraries, such as (Fig. 2)

- All the academic libraries created in different regional sites of the UASD: CURSA (Centro Universitario Regional de Santiago), CURA (Centro Universitario Regional Atlántico-Puerto Pla-

\footnotetext{
${ }^{11}$ In 1995, The European Commission hosted the conference of G7 ministries in Brussels to discuss the means by which to "encourage and promote the innovation and development of new technologies, including, in particular, the implementation of open, competitive, and world-wide information infrastructures." See 〈http://europa.eu.int/ISPO/intcoop/g8/i_ g8conference.html $\rangle$. When in the developed countries and in the old Europe the Global Information Society was formally stated, in the Dominican Republic, it started the most important time for libraries and information services in the country.

${ }^{12}$ Ley General de las Telecomunicaciones No. 153-98, 27 de Mayo de 1998. Santo Domingo: INDOTEL (2004). Available online at: 〈http://www.indotel.org.do/(4osqcl55j0aenozabfek3m55)/ ley_153-98.aspx $\rangle$.

${ }^{13}$ OPTIC: Oficina Presidencial de Tecnologías de la Información y Comunicaciones: 〈http://www.optic.gov.do〉.

${ }^{14}$ Dominican Republic Telecommunications Profile 2006 (Index Mundi): 〈http://www.indexmundi.com/dominican_ republic/telecommunications_profile.html $\rangle$.
}

ta), Centro Universitario Regional de Nagua, Centro Universitario Regional del Este-Higüey.

- Villa Duarte Public Library.

- New building of the only public university in the country, Autonomous University of Santo Domingo (UASD) (Figs. 2 and 3).

Furthermore, all these new libraries have created Technological Communitarian Centers (CTC, Centros Tecnológicos Comunitarios). Inspired by American community colleges, the CTCS are special information centers where there are combined Internet technologies and librarianship concepts, establishing a democratic access to information through public spaces created specifically for that purpose. CTCs have been created in different areas of the country: Castanuela-Monte Cristi, El Seibo, Sabana de la Mar (Hato Mayor), Sabana Iglesia (Santiago) y Nagua (Fig. 4).

To be effective, an information policy needs adequate funding and to ensure the appropriate laws and regulations are in place to guarantee access to information, and information society infrastructures. Current information policies in the country could be defined as "information for development" initiatives, working to promote better understanding and effective use of information services and information and communication technologies (ICTs) as tools of poverty reduction and broad-based sustainable development. A specific and formal investment has been designated to improve libraries and information services in the country. A legislative bill exists to promulgate the so-called "culture code", which will address rights issues concerning libraries, museums, archives, and copyright law. In this context there is a need for highly qualified information professionals to deal with all this information and technological development.

\section{Assessing librarians' and information professionals' education in Dominican Republic}

In general, librarians are educated in universities in what used to be called "library schools" or "LIS schools" at different levels: undergraduate (diploma or bachelor), masters (MLIS, MLS, and other varieties) and doctorate (Ph.D.), depending largely on the overall educational tradition in the country or region. This is usually supplemented by periods of practical training and experience and increasingly Continuing Professional Education (CEP) and online courses. In some countries this leads to a 


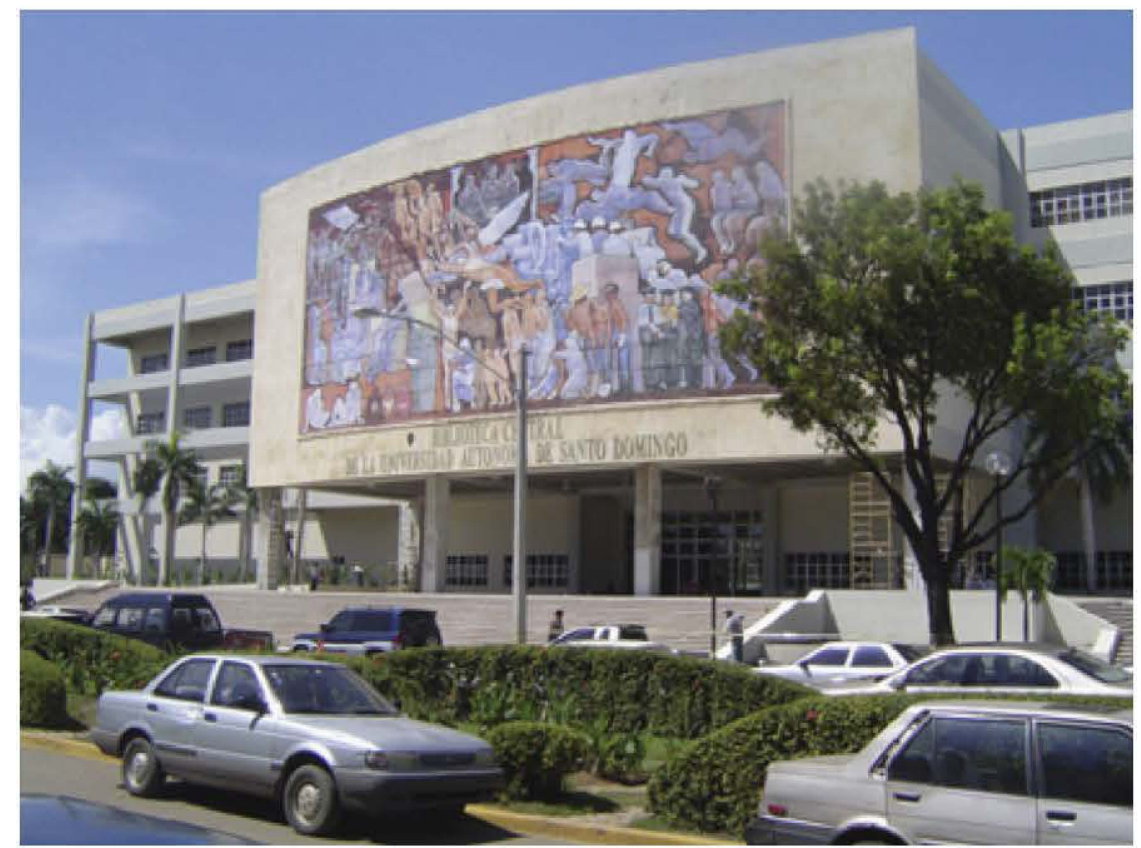

Figure 2 Library of the University Autonomous of Santo Domingo (UASD) 2005. (Picture by MyT Soluciones Documentales).

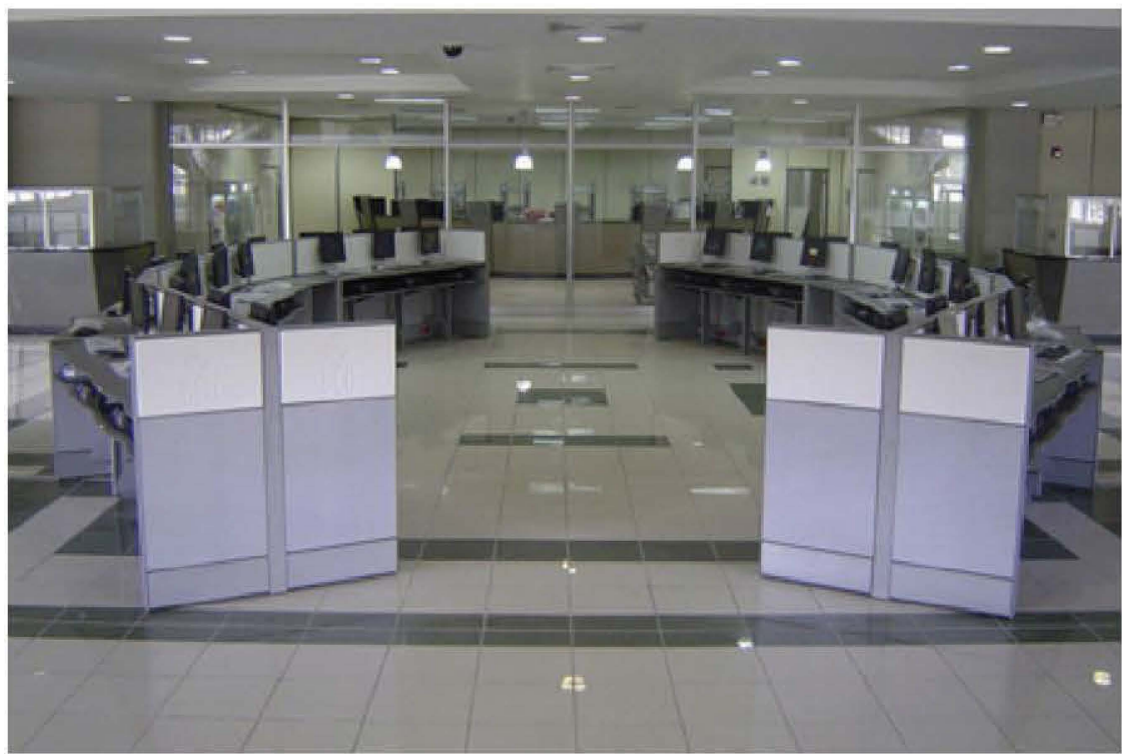

Figure 3 Library of the University Autonomous of Santo Domingo (UASD) 2005. OPAC Area (Picture by MyT Soluciones Documentales).

license to practice; in others - such as the USA, Canada and Puerto Rico - the programs themselves are accredited by a professional body. Curricula of these courses often include studies of information science, traditional librarianship, management techniques, computer-based information systems, electronic publishing, understanding user needs, and legal considerations, including intellectual property laws. This is in addition to the more traditional subjects such as reference sources, cataloguing, indexing and classification.
We think that the current information situation in the country suggests a need for a deep analysis of professional skills and education.

\section{Perceptions, methodology and scope of this study}

The general perception of librarians in the country is that there is a strong lack of qualified professionals in librarianship in the Dominican Republic. 


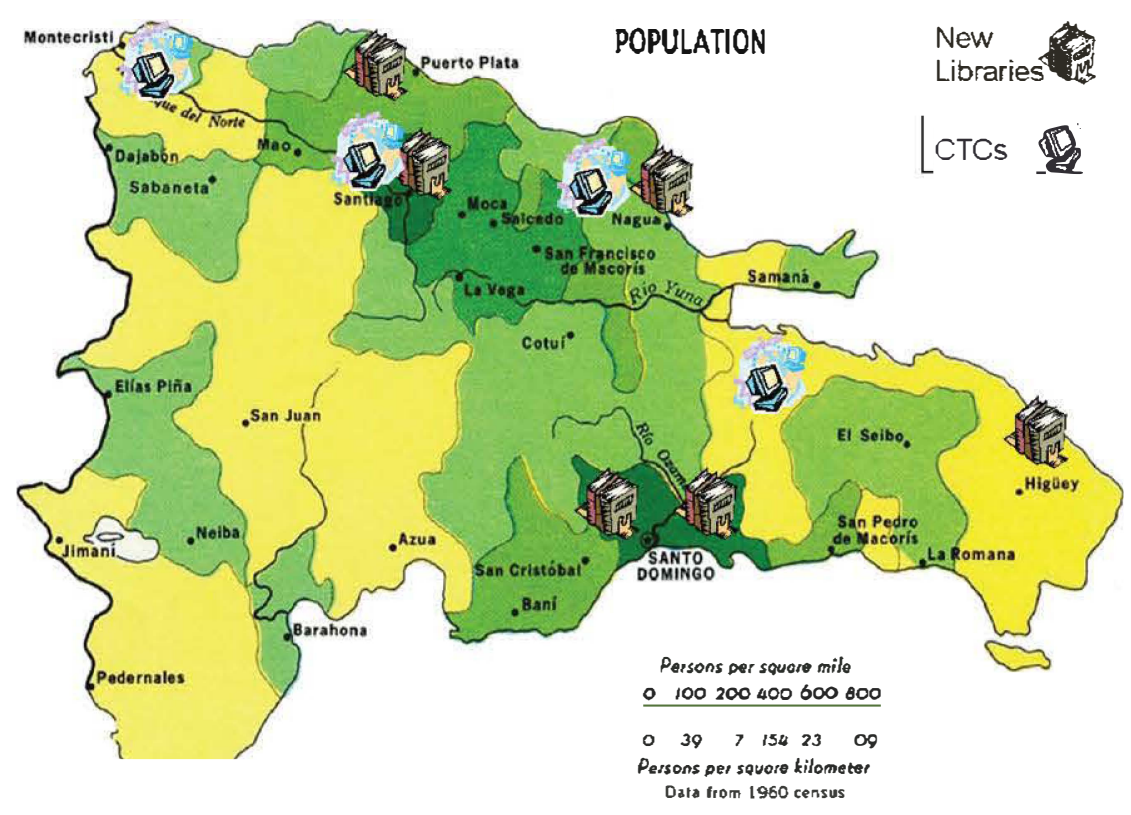

Figure 4 Geographical distribution of the new Libraries and Communitarian Technological Centers (CTCs) created in Dominican Republic. Note: Based on Dominican Republic Population Map, from Map N. $78962-1971$ at Perry Castañeda Library Map Collection: 〈http://www.lib.utexas.edu/maps/dominican_republic.html〉.

The lack of a good LIS school in the country has limited the professional development in the area (Núñez de Taveras, 1997, etc.). Dulce M. Núñez made a survey asking professionals in the Dominican Republic about their level of education. The results are reflected in the following table.

This data reflected the situation nine years ago, but the situation has not changed a lot (cf. "Information professionals in Dominican Republic: an appraisal"). In general, the situation is similar and grievous, considering the new information development in the country that we have mentioned previously. The development of libraries and digital technologies and the emergence and ubiquity of information in the country prompts us to ask whether individuals and institutions are able to absorb this cultural growth and create real development for the country.

We had the perception, based on the knowledge of old Dominican libraries as well as the new libraries, resources centers, CTCs, etc. created in the country (Fig. 4), that Dominican professionals need strong and formal LIS studies, as well as continuing education programs. We made this qualitative analysis of the real situation to assess whether current librarians and information professionals can lead the national information society and address national development to make selfevident the need for LIS programs to have real, qualified professionals to deal with the develop- ment of the information society in the country. The methodology used for this study was:

(1) To identify the institutions and stakeholders in Library and Information Science education in the country.

(2) To visit those institutions which in some way play or have played a role in LIS Education in Dominican Republic.

(3) To collect the scarce and sparse bibliography and information about library studies in the country.

(4) To interview the main actors, educators, or those educated in LIS in the country.

(5) To have a joint meeting with people representing the main educational institutions related to LIS Education in the Dominican Republic, especially the Technological Institute of Santo Domingo (INTEC), Madre y Maestra Pontifical Catholic University (PUCMM), Iberoamerican University (UNIBE), the Association of Dominican University Libraries (ABUD) ${ }^{15}$ and the Autonomous University of Santo Domingo (UASD), as well as some particular outstanding information professionals in the field in the country.

\footnotetext{
${ }^{15}$ This meeting happened in FUNGLODE (Fundación Global Democracia y Desarrollo) in Santo Domingo on Friday, August 4 , 2006.
} 
This paper limits its study to the actual offering of LIS courses in a University context. Not considered are the short courses (two-to-three day courses) organized by FUNGLODE (Fundación Global Democracia y Desarrollo), ABUD (Asociación de Bibliotecas Universitarias Dominicanas), other particular institutional or even personal efforts.

\section{LIS education experiences in Dominican Republic}

As we have stated before, it is very difficult to determine what the education and training offered in Dominican Republic in Library and Information Science, actually is because the web information about universities and studies in the country is not visible, not homogenous, and usually out of date, and because the sources about LIS Education in Latin American and the Caribbean are not detailed enough or are not described at all. Thus, it is difficult to determine whether the schools and training opportunities reflected there are the real and appropriate ones or not. Some particular cases are, for instance:

- The inventory of Schools of Librarianship and Information Studies in Latin America collected by The Robert Gordon University (UK) ${ }^{16}$ only identifies the studies of Librarianship and Information Science (Bibliotecología y Ciencia de la Información) of the INTEC (Instituto Tecnologico de Santo Domingo), which is a course offered on the Web, but actually never taught. ${ }^{17}$

- The UNESCO Libraries Portal ${ }^{18}$ only pointed to Universidad Dominicana O\&M, ${ }^{19}$ which has postgraduate studies on Auditory of Computerized Systems, whose requirement is to have a degree in Informatics Engineering, Systems and Computer Science or Accounting and audit. The courses are also centered on accounting and audit and management of computer centers.

- In other cases, the main sources on LIS Education in Latin America do not cover the Dominican Republic's situation at all. That is the case for

\footnotetext{
${ }^{16}$ Schools of Librarianship and Information Studies in Latin America. Aberdeen: The Robert Gordon University, [March 3, 2005]. Available online at: 〈http://www.rgu.ac.uk/files/ SCHOOLS-ADD\%5B1\%5D.doc >.

${ }^{17}$ See section "Current LIS education and training experience".

${ }^{18}$ UNESCO Libraries Portal $>$ Training $>$ Institutions $>$ Latin America (2005): 〈http://www.unesco.org/webworld/portal_ bib/pages/Training/Institutions/Latin_America/index.shtml $\rangle$.

${ }^{19}$ Universidad Dominicana: 〈http://www.udoym.edu.do/〉 (Added to UNESCO Libraries Portal. Institutions for Training in Latin America, on October 31, 2000)
}

example, of INFOLAC (1999) ${ }^{20}$ or InformationR. Net (2006). ${ }^{21}$

This reality pushes us to make this qualitative approach to LIS education in the country, with the help of the librarians and main information professionals in the country using interviews and surveys.

\section{Historical overview of LIS Education in Dominican Republic}

As happened in other Latin American countries with long dictatorial periods, the Dominican Republic had three decades during Trujillo's dictatorship (1930-1961) where culture was limited to intellectual elites, who lived out of the country most of the time. Libraries and, of course, librarianship education were neglected. The first librarians were trained outside the country in the 1960 s or 1970 s, mainly in the school of Librarianship of the Universidad Interamericana in Medellín, Colombia, and in the LIS school of Rio Piedras of the Universidad de Puerto Rico.

The first librarianship school in the country was founded in 1979 at the now defunct Universidad Mundial. It was the first school at the university level, but it only worked for four years. The program graduated 39 people, who aided the development of libraries in the country during the 1980s. After the Universidad Mundial, a group of graduates of that course founded the Centro de Estudios Profesionales (CEP, Center of Professional Studies) endorsed by the National Education Council, which also disappeared because they did not have enough students.

After the unlucky attempts of Universidad Mundial and the CEP at creating university level programs, a group of traditional librarians made another effort and got approval for LIS studies within the Pedagogy degree, endorsed by University Council of the UASD (Autonomous University of Santo Domingo) in 1995.

\section{Current LIS education and training experiences}

The current situation of LIS education in the Dominican Republic has as its basis the commendable desire of the small group of traditional graduate librarians to see an improvement in both

\footnotetext{
${ }^{20}$ INFOLAC is the Program of Information Society for Latin America and Caribbean. In its directory of Institutions that teach librarianship in this region there are only the schools of Argentina, Bolivia, Brazil, Chile, Colombia, Costa Rica, Cuba, Ecuador, Guatemala, Jamaica, Mexico, Panama, Paraguay, Peru, Uruguay and Venezuela.

${ }^{21}$ This resource only covers LIS schools of Argentina, Brazil, Chile, Colombia, Costa Rica, Cuba, Mexico, Peru, Puerto Rico and Uruguay.
} 
the quality and the status of qualification in librarianship. Those professional librarians, as well as some institutions, are the protagonists for LIS training in the country. Although Concepción (2005) stated in a digital edition of the Newspaper Listín Diario that the Autonomous University of Santo Domingo (UASD) is the only place in the country where the degree in librarianship is taught, this is not true. There are other initiatives, also endorsed by universities, which include some sort of LIS education. We will describe those initiatives working to correct the insufficient LIS studies offered in the country. We describe them by institution instead of by degrees, which will be more appropriate, first, in order to give them suitable credit and second, because it is difficult to typify the usual LIS degrees.

\section{INTEC Academic Library}

The private University Technical Institute is another traditional and committed institution training librarians in the country. The INTEC university librarians have planned and taught different courses since 1978. Their main initiatives have been and are:

- Course for assistant librarians (1978-1993). They trained around 400 people to serve as auxiliary staff in libraries. It was a very demanding and intensive course of $165 \mathrm{~h}$ distributed through 3 months.

- Course for training teacher-librarians ${ }^{22}$ (1994-2000). This course was an initiative to educate school teachers, with degrees in education, in library skills. It was funded with a loan from Interamerican Development Bank and coordinated with PUCMM in order to cover all the country. They trained 220 teacher-librarians, 88 students of the North region (PUCMM) and 132 from the rest of the country (INTEC).

- Graduate in librarianship and information science. This title is the result of a thoughtful initiative to create a formal university degree in LIS in the Dominican Republic. INTEC offered this title as a bachelor program in 2003, but these

\footnotetext{
${ }^{22}$ They call it in Spanish "maestro bibliotecario", but the translation should not be "master" because with a course of this nature you cannot get the MLS/MLIS degree, and it was actually addressed to teachers at public schools in the country. This title makes sense because unlike in other countries, school professional librarians are legally recognized by Dominican regulation of public education institutions (Ley 66, 1997). This law states: will be designated librarians in all Education Centers where there are libraries, whose requirements are: (a) To be graduated in Librarianship or, at least, a teacher who has done the training courses in the field [...]."
}

studies never started, even though it was approved by the National Higher Education Council and it is still offered. It was a threeyear BLIS program, and the students (if it had any) would become "graduates in librarianship". For the first time there was a formal title comparable to LIS studies in most countries. Even though the curriculum included some surprising subjects such as Mathematics I, II and III, Human Beings and Nature, and Dominican Social History I and II, this probably was not the reason there were never students. ${ }^{23}$ The real reason might be because of the credits price at INTEC (around US\$25 each credit) or perhaps because it seemed to be a very exhaustive and complete course for the kind of usual LIS students: practitioners without a specific academic title, or old librarians who might want to update their knowledge by having a new degree.

\section{PUCMM. "Rafael Herrera y Cabral" Library}

The Madre y Maestra Pontifical Catholic University has made outstanding attempts to educate librarians and information professionals in the country in recent years. The PUCMM is an important private higher education institution in the country, whose library director has taken on (as also happened in the INTEC or UNIBE cases) the commitment of offering different kinds of education in Librarianship and Information Science, with the endorsement of the University. It tries to fill the gap between the lack of an LIS school and the information professionals urgently needed in the country. The following training programs have been offered:

- Librarianship and Information Science Diploma (2004). A course of $300 \mathrm{~h}$ addressed to graduates of any university degree. This diploma includes the following curriculum ( $45 \mathrm{~h}$ each course): Technologies applied to LIS I and II; information description and analysis (cataloging); classification and subject headings; collections development; information resources and reference services and Multimedia.

- Basic Course on Information Centers Organization $^{24}$ (2005). It is a 92-h course addressed to those people interested in learning about librar-

\footnotetext{
${ }^{23}$ See the Academia Programme on Librarianship and Information Science offered by INTEC since 2003 at $<$ http: / / www.intec. edu.do/programas/hum/bci.html $\rangle$, and for the detailed description of the curriculum, see <http://www.intec.edu.do/ programas/hum/pbci.html $>$.

${ }^{24} \mathrm{To}$ analyze in detail the conditions, objectives and curriculum of this course, see <http://rsta.pucmm.edu.do/biblioteca/ biblioespacio/brochurecurso\%5B2\%5D.pdf $\rangle$.
} 
ianship and working in information centers. The curriculum is composed of six main subjects: document description; content analysis of documents; reference service; bibliography; serials and information technologies in information units.

- Certificate of master in Library sciences (MLS) (2005). This title constitutes an interesting, innovative and convenient initiative. It is one of the products of the General Agreement of Dominican Universities with University of Puerto Rico. According to this agreement the PUCMM will select 15 participants from different academic institutions belonging to the General Agreement with University of Puerto Rico. Candidates will be selected over 5 years in such a way that the number of beneficiary students will reach 75 . The first experiment was in 2005, and the MLS program was a hybrid course (online and onsite), where the teachers from the Graduate School of Information Sciences and Technologies of the University of Puerto Rico went to Santo Domingo at the beginning of each academic module. After that, the students followed their courses using Blackboard e-learning software. The curriculum of this 22 credits/ 18 months program was a computer use literacy workshop and Blackboard use workshop, plus a series of specific courses: Social Information Interchange; Workshop of Internet as Curriculum Resource; Information Needs Diagnosis; Access Policies and Information Services; Information Organization and Retrieval; Libraries Administration; Librarian's Role in Higher Education; Clinical Experiences and Multimedia Creation. It is the first online program from the University of Puerto Rico and a good experience for academic librarians who have not specialized in LIS studies in Dominican Republic. ${ }^{25}$

\section{UASD Department of Pedagogy}

The Public University in the country does not offer a specific LIS degree; they offer subjects on librarianship inside the graduate studies on Education, which is, once again, a way of improving the deficient LIS education in the Dominican Republic this time from the public academic sector. Within this curriculum in Education they established two programs that are not very clearly described. ${ }^{26}$

\footnotetext{
${ }^{25}$ For further information please see Novel programa academico. San Juan: Universia Puerto Rico, January 18, 2005. Available online at 〈http://www.universia.pr/portada/actualidad/noticia_actualidad.jsp?noticia $=20677\rangle$.

${ }^{26}$ For example, the webpage does not usually work; different professionals have different knowledge of the courses they teach, etc.
}

- If the students follow only four semesters, they receive the title of "Technician in Librarianship". The curriculum for these semesters includes courses like: Institutional Orientation; Introduction to Philosophy; Spanish Language and Techniques of Expression I and II; Introduction to Education; Introduction to Dominican Social History; Introduction to Psychology; Basic English I and II; General Geography. Island. Santo Domingo; and also Cataloging I and II; Classifications I and II; Periodicals; Bibliography; Reference I; History of the Book and Libraries; Introduction to Computer Science and School; and Public Libraries.

- If the students continue four more semesters (a total of eight), they receive the title of Graduate in Education with "Mention in librarianship". These four further semesters include subjects like: Intermediate English, Introduction to General History of Literature; Human Relationships in Education; Introduction to Economics; Philosophy of Education; School Hygiene and Health Education; History of Arts; Social Pedagogy; Professional Ethics; Reference II; Bibliographic Research; Information Science Foundations; Academic and Specialized Libraries; Library Automation; Library Administration; Dominican Bibliography; Information Service Planning; Document Preservation and Restoration and Comparative Librarianship. At the end of their courses, the students have to produce a graduate thesis or take courses equivalent to eight credits.

\section{UNIBE}

The Iberoamerican University in Santo Domingo offers as well some training for practitioners, but not in a formal academic degree. Their offerings are:

- Advanced course on Librarianship (since 1998): This is a three semesters' course addressed to librarians in service, professionals in other knowledge areas and graduates. The students attend 5 subjects per semester for a total of 36 credits, and it is supposed that they acquire the elements and skills they need to work as library assistants or auxiliary librarians. At the end, they receive a certificate of attendance at "a one year course" on Advanced Librarianship. The specification of "one year" is to clarify the difference with other traditional courses offered in the country. The curriculum is not as advanced as we might think from its title. It includes subjects like: Introduction to Library and Information Sciences; Description 
Table 1 Distribution of library staff by library type in Dominican Republic (Núñez de Taveras, 1997)

\begin{tabular}{|c|c|c|c|c|}
\hline Library type & Ph.D. & MLIS & BLIS & Professionals from other areas \\
\hline National Library & & & 4 & 10 \\
\hline University libraries & & 4 & 23 & 257 \\
\hline Public libraries & & & 2 & 118 \\
\hline School libraries & & 2 & 1 & 68 \\
\hline Specialized libraries & & & 11 & 81 \\
\hline Total & & 6 & 41 & 534 \\
\hline
\end{tabular}

Note: Ph.D.: librarians with doctoral degree; MLIS: librarians with master degree; BLIS: librarians with bachelor's degree ( 3 years of librarianship studies).

of Bibliographic Materials; Reference I and II; Computer Science Applied to Librarianship; Management of Information Units; Classification Systems; Information Applied to the Library; Serials or Bibliography. It also requires a research project at the end of the course, which is pretty unusual for a course of this nature in international LIS programs.

- Courses for Assistant librarians. UNIBE also offers these basic courses, with an extension of three months, teaching mainly: Classification, Cataloging and Reference. This is usually taught at the National Library or in different University libraries.

There are other periodic experiments in continuing professional education in librarianship or technologies, currently offered by these or other institutions in the country. These have, at most, been two-day courses taught by international professors or professionals in the field. But given the formal university studies described above, the current level of LIS Education in the country is not enough and is often out-of-date for 21st century professionals who deal with Information Society development in the country.

\section{Information professionals in Dominican Republic: an appraisal}

The majority of the staff in libraries gained their professional qualifications, not by attending library school, but by everyday practical experience. Most librarians in the country are practitioners without a specific LIS degree, and they call themselves "empirical librarians". It is very common that some of those "empirical librarians" follow one of the studies, courses, etc. described in "Current LIS education and education and training experiences" at the same time as working as librarians in order to get a specialized title which legitimates them in their profession.

The first librarians of the country were trained outside the country in the 1970s or 1980s (mainly in Colombia or Puerto Rico but also in the United States of America). Dominican Republic had between 1970 and 1990 , only 8 professionalgraduated-librarians (Concepción, 2005). It is easy to figure out what is the training origin of the 48 graduated librarians reflected in Núñez's survey in 1997 (Table 1): those 8 trained out of the country, 39 from Universidad Mundial, and one Ph.D. Who was trained in Russia. Most of them work at University libraries, especially private ones, where their salaries motivate them.

The professional degree and qualifications have not changed much since 1997. At most, there may be some new bachelors degrees granted in Education with the "mention in librarianship" at the UASD, around 250 people who took the "Advanced Librarianship Course" at UNIBE, around 150 more "teacher-librarians" from PUCMM and INTEC, and the 15 with the certificate of the PUCMM and University of Puerto Rico online program, 2 MLIS graduated in Spain and, of course, a lot of new auxiliary staff who have taken three-month courses on basic librarianship.

\section{Conclusions, recommendations and further initiatives}

The Dominican Republic, as well as other developing countries of the region, requires a core of qualified information professionals to meet the new demand of educators, politicians and the private sector. There is growing awareness about information, and there is a change in the way people communicate, learn, find and use information. From this study and analysis of LIS Education in 
the Dominican Republic, the following inferences may be drawn:

- Current LIS training offered in Dominican Republic has obsolete curricula, or at least not innovative enough to meet the needs of the new information infrastructure. Librarianship studies should be innovative, educational options should be open to current practitioners, new students, and even instructors, and the curricula should be designed to prepare future professionals to anticipate developments, solve problems, and construct the new democratic Information Society.

- There is a traditional and current lack of students who attending LIS educational initiatives in the country. There is general discredit for these studies in the country and too many unsuccessful training initiatives (Universidad Mundial, CDEP, INTEC program of 2003). The worst is that no young students see Librarianship studies as academic and professional options. A good LIS school and promotion of the information professional profile would be very helpful for creating a new generation of librarians.

- The students who attend some of these LIS education initiatives are always practitioners who want to jump from the indigence of professionalism to the supposed excellence of a university title.

- There is disrespect for the profession in Dominican Republic. The general perception of the Dominicans is that study is not necessary to become a librarian or information professional. ${ }^{27}$ This is probably due to the general thinking that it is not necessary to have a university degree for being an information professional, and also because they have no economical acknowledgment reflected in their salaries.

- LIS education in the country, except in the context of Universities, is always in the practitioners' hands, rather than in those of researchers or LIS professors. There is not any kind of research in information science and librarianship. This is a common chicken-andegg situation in Latin America: They have no Ph.D. programs/research because they do not have doctoral graduates to teach and research, but they have no doctors to teach and research because they have no Ph.D. programs. In the

\footnotetext{
${ }^{27}$ One of our Dominican colleagues, who attend the meetings we held for this paper, told us ironically but sadly: "In this country, someone who knows how to read and write could be a librarian".
}

Dominican Republic this situation is even worse, because it happens not only at the doctoral level but at any level (MLIS/MLS and graduate).

- A lot of the circumstances revealed by this study made us think that e-learning or hybrid study using online technologies could be the key to solving the lack of updated and quality LIS education in Dominican Republic. Some of these circumstances are:

- The ICT and Internet development in the country and the existence of Communitarian Technological Centers (CTCs) in the country.

- The success of the online experiment (actually a hybrid course) of PUCMM with University of Puerto Rico.

- The success of other e-Learning experiments in developing countries and the Organization of American States OEA's recommendation, which understands e-learning as a real challenge for this kind of countries. ${ }^{28}$

- The fact that a lot of practitioner librarians want to follow academic training at the same time as they work as librarians.

- We recognize that there are a lot of actions to take in order to improve this situation, of both the general low qualification of current information professionals and the lack of strong LIS programs, which could enhance the librarian's image in the society. One of these actions could be the creation of a professional association. There was one called ABIDORD (Dominican Librarians, Archivist and Information Scientists Association), but it does not exist anymore. The only professional organization is ABUD (Dominican Academic Librarians), which includes the directors of libraries of the private universities, ex officio. A professional organization might develop solutions for the main problems we have pointed out.

Throughout this paper we demonstrate that stronger and more up-to-date LIS education is needed in the Dominican Republic. In such a way a new generation of graduated information professionals could deal with the challenges of getting this wonderful Caribbean country into the Information Society, giving the Dominicans a real democratic access to information.

\footnotetext{
${ }^{28}$ OEA. Desafíos para la Comunidad Educativa. Portal Educativo de las Américas, October 2005. Available online at: 〈http://www.educoea.org/portal/es/tema/editorial2005/ oct05 r.aspx?culture=es\&navid=1 $\rangle$.
} 


\section{Acknowledgments}

The authors want to thank all the information professionals in the Dominican Republic who attended our meetings in August 2006 for evaluating and discussing LIS education and for the valuable information they gave to us, especially: Dulce M. Núñez (PUCMM), Lucero Arboleda (INTEC) and Miriam Michel (UNIBE). We also want to thank Kate Johnson and Toni Carbo for their thoughtful comments to this paper.

\section{References}

Concepción, Yndira (2005). Sólo la UASD gradúa bibliotecarios. Listín Diario. Edición Digital, August, 2 2005. Available online at: 〈http://www.listin.com.do/antes/agosto05/020805/ ventana/ventana.htm $\rangle$.

Fang, Josephine R., Stueart, Robert D., \& Tuamsuk, Kulthida (1995). World guide to library archive and information science education, 2nd rev. and enlarged ed. München, New Providence: Saur.

Fernández, Leonel (2004) 40 ofertas culturales para el fomento de la Cultura: la cultura con Leonel 2004-2008. Santo Domingo.

Gupta, Sushma, \& Gupta, Davendrak (1997). Development of Library and Information Science Education in Africa. International information and Library Review, 29, 95-107.

IFLA-ETS. (2006). LIS Education in Developing Countries Discussion Group (2006-2007). IFLA. Education and Training Section, 17 April 2006. Information Available online at: $\langle$ http://www.ifla.org/VII/dg/lisdg/index.htm 〉.

INDOTEL. (2004). Historia de las Telecomunicaciones en República Dominicana. Santo Domingo: Instituto Dominicano de Tecnología. Available on line at: 〈http://www.indotel.org. do/(1fpwcnj1p2qi2a451lv4fsb4)/historia.aspx $\rangle$.

INFOLAC. (1999). Programa de la Sociedad de la Información para América Latina. Escuelas de Bibliotecología. Directorio de Instituciones sobre el Área de Bibliotecología y Ciencia de la Información de Iberoamérica y El Caribe. INFOLAC, updated 1999. Available online at: 〈http://infolac.ucol. $\mathrm{mx} /$ directorio/escuelas.html $>$.

InformationR. (2006). World List of Departments and Schools of Information Studies, Information Management, Information Systems, etc. Other countries of the World. InformationR. Net, January 2006. Available online at: 〈http://informationr.net/wl/wlist 7.html $>$.

Johnson, lan M., et al. (2001). Management education in Latin America and the Caribbean. Education for information, 19(1), 3-18

Kargbo, John Abdul (1999). Library education and the practitioner: The Sierra Leone experience. International information and Library Review, 31, 97-103.

Karisiddappa, C. R. (2004). Library and information science curriculum for the developing countries. In World Library and information Congress. IFLA General Conference and Council, Vol. 70, 2004, Buenos Aires. Available online at: 〈http:// www.ifla.org/IV/ifla70/papers/062e-Karisiddappa.pdf $\rangle$.

Ley 66. (1997). Consejo Nacional de Educación. Reglamento orgánico de las instituciones Educativas Públicas. Available online at: 〈http://Www.educando.edu.do/NR/rdonlyres/ 100542C6-47EE-4BCB-8AA4-2903C4D172FD/0/reglamentoinst publicas.doc $>$.
Licea de Arenas, Judith (coord.) (2001). Cuarenta y cinco años de estudias universitarios en Bibliotecología: visiones empíricas e históricas. México, D. F.: UNAM, Facultad de Filosofía y Letras.

Maris, Femández Stella, \& Giunti, Graciela María (1999). Planes de Estudio de las Escuelas de Bibliotecología, Archivología y Museología de Iberoamérica. Buenos Aires: Sociedad de Investigaciones Biblotecológicas, Progreso de la Bibliotecología en el Tercer Mundo ALP/IFLA.

Martínez Arellano, Filiberto F., \& Calva González, Juan Jose (comp. ) (2005). Seminario INFOBILA como apoyo a la investigación y educación bibliotecológica en América Latina y el Caribe: Memoria 16, 17 y 18 de marzo 2005. México, D.F.: Universidad Nacional Autónoma de México.

Morales Campos, Estela (1997). América Latina y el Caribe. In A. Large Andrew (Ed.), informe Mundial sobre la información: 1997/98 (pp. 114-129). Paris: UNESCO.

Núñez de Taveras, Dulce M. (1997). Informe Nacional- República Dominicana. In Tools for Library Development: Proceedings of the workshop, Martinique, March 10-13, 1997. IFLA (ALP, RSCLAC and ROLAC). Uppsala University Library.

Núñez de Taveras, Dulce M. (2006). Desarrollo de la biblioteca en la República Dominicana. Hoy Digital (El País), 19 de marzo de 2006. Available online at: 〈http://hoy.com.do/app/ article.aspx?id=69217 > and 〈http://rsta.pucmm.edu.do/ biblioteca/html/notidesarrollo.htm $\rangle$.

Rodríguez, Adolfo (2006). Library Education in Latin America and the Caribbean. In Forum on international Library Education (2006 ALA Annual Conference). Sponsored by ALA President Michael Gorman (New Orleans, Friday, June 23, 2006). Available at: 〈http://mg.csufresno.edu/papers/forum_2/ rodriguez.pdf $\rangle$.

Shimmon, Ross (2003). Role and position of libraries. IFLA, World Summit on the Information Society, Geneva, 2003-Tunis 2005. February 12, 2003. Available online at: 〈http://www. ifla.org/III/wsis_a.html $>$.

Tannuri de Oliveira, Ely Francina, \& Chaves Guimaraes, José Augusto (2004). Library professionals' education in the Mercosur countries. Education for information, 22, 31-39. 
Dr. Eva Mạ Méndez Rodríguez 〈emendez@bib.uc3m.es〉 is an Associate Professor at the University Carlos III of Madrid, where she has been teaching and researching since March 1997. She holds a Ph.D. (cum laude) in Information Science from the same University, awarded in the academic year 2001-2002 as the outstanding thesis in her field. Her research and previous publications focus on Semantic Web technologies applied to digital information systems and services, as well as on informa-tion and technology policies for Information Society develop-ment. She has featured as keynote speaker in different conferences all around the world, especially in Latin American countries, where she also worked in several consultancy activities and projects. Notably, she is International Consultant of the Government of Dominican Republic on Cultural Policies, Libraries Development and Information Society since December 2005. Dr. Mendez was Fulbright-EU Research Scholar at Uni-versity of North Carolina at Chapel Hill during the academic year 2005-2006.

Aida E. Montero 〈a.montero@funglode.org > has been the Director of the Knowledge Management and Information Center of FUNGLODE (Fundación Global Democracia y Desarrollo) in Santo Domingo (Dominican Republic) since its creation in 1999. She cúrrently serves as Information Advisor of the Government of Dominican Repúblic (2004-2008) leading some of the State projects focúsed on creating new libraries and enhancing information infrastrúctúre in the coúntry. She holds a degree on Systems Engineering from INTEC (Institúte Tecnológico de Santo Domingo), where she also completed the coúrse for library assistants at the same University (INTEC) in 1998, and she followed MUS stúdies at University Carlos IIl of Madrid (2002). Both at FUNG LODE Knowledge and Information Center and at her government responsibilities, her work and research has been focúsed on library creation and modernization, inclúding library aútomation and technology center constrúction. 